\title{
Article
}

\section{Heavy Metal(loid)s Contamination in Ground Dust and Associated Health Risks at a Former Indigenous Zinc Smelting Area}

\author{
Shan $\mathrm{Li}^{1,2}$, Xiangyang $\mathrm{Bi}^{3}$, Zhonggen $\mathrm{Li}^{1,4, * \mathbb{C}}$, Heng Wang ${ }^{5}$, Xinyu $\mathrm{Li}^{1,2}$, Xinbin Feng ${ }^{1}{ }^{\mathbb{D}}$, Guangyi Sun ${ }^{1,2} \mathbb{D}^{\mathbb{D}}$, \\ Ji Chen ${ }^{1}$ and Bo Meng ${ }^{1, *}$ \\ 1 State Key Laboratory of Environmental Geochemistry, Institute of Geochemistry, \\ Chinese Academy of Sciences, Guiyang 550081, China; lishan@mail.gyig.ac.cn (S.L.); \\ lixinyu@mail.gyig.ac.cn (X.L.); fengxinbin@mail.gyig.ac.cn (X.F.); sunguangyi@mail.gyig.ac.cn (G.S.); \\ chenji@mail.gyig.ac.cn (J.C.) \\ 2 University of Chinese Academy of Sciences, Beijing 100049, China \\ 3 State Key Laboratory of Biogeology and Environmental Geology, School of Earth Sciences, \\ China University of Geosciences, Wuhan 430074, China; bixy@cug.edu.cn \\ 4 School of Resources and Environment, Zunyi Normal College, Zunyi 563006, China \\ 5 School of Public Management, Guizhou University of Finance and Economics, Guiyang 550025, China; \\ hengwang198510@126.com \\ * Correspondence: lizhonggencn@126.com (Z.L.); mengbo@mail.gyig.ac.cn (B.M.)
}

check for updates

Citation: Li, S.; Bi, X.; Li, Z.; Wang, H.; Li, X.; Feng, X.; Sun, G.; Chen, J.; Meng, B. Heavy Metal(loid)s Contamination in Ground Dust and Associated Health Risks at a Former Indigenous Zinc Smelting Area. Int. J. Environ. Res. Public Health 2021, 18, 893. https://doi.org/10.3390/ ijerph18030893

Received: 12 December 2020

Accepted: 15 January 2021

Published: 21 January 2021

Publisher's Note: MDPI stays neutral with regard to jurisdictional claims in published maps and institutional affiliations.

Copyright: (c) 2021 by the authors Licensee MDPI, Basel, Switzerland. This article is an open access article distributed under the terms and conditions of the Creative Commons Attribution (CC BY) license (https:// creativecommons.org/licenses/by/ $4.0 /)$

\begin{abstract}
Indigenous zinc smelting (IZS) is a backward technique that releases a great deal of heavy metal(loid)s into the environment. However, the contamination of heavy metal(loid)s in ground dust and the associated health risks in such areas are poorly known. In this study, a former IZS area in Guizhou, China, was surveyed during 2008-2018 with 15 elements (Ag, As, Bi, Cd, Co, Cr, $\mathrm{Cu}, \mathrm{Hg}, \mathrm{In}, \mathrm{Ni}, \mathrm{Pb}, \mathrm{Sb}, \mathrm{Sn}, \mathrm{Tl}, \mathrm{Zn}$ ) being analyzed. The results indicate that most elements (e.g., $\mathrm{Ag}, \mathrm{As}, \mathrm{Cd}, \mathrm{Cu}, \mathrm{Pb}, \mathrm{Sb}, \mathrm{Sn}, \mathrm{Zn}$ ) in ground dust decreased significantly after the cessation of the IZS in 2006; nevertheless, some elements still remained at relatively high levels in 2018, e.g., $\mathrm{Pb}$ (average: $762 \pm 647 \mathrm{mg} / \mathrm{kg}$ ), Zn (average: $1287 \pm 753 \mathrm{mg} / \mathrm{kg}$ ), Cd (average: $7.76 \pm 5.06 \mathrm{mg} / \mathrm{kg}$ ), and As (average: $41.9 \pm 34.8 \mathrm{mg} / \mathrm{kg}$ ), indicating they might come from the local contaminated soils, slag residues and smelting potteries. In terms of the impacts on human health, children have both higher non-carcinogenic and carcinogenic risks than that of adults, with the latter subpopulation having a lower risk than the threshold values. $\mathrm{Pb}$ and As were the two elements with the highest noncarcinogenic risk for children, the hazard index of local children was still higher than the threshold of 1 (e.g., 1.43 for As, 2.09 for $\mathrm{Pb}$ ) in 2018. The carcinogenic risk of As exposure to children dropped more than two times to $6.42 \times 10^{-7}$ in 2018 , which falls below the tolerable range $\left(10^{-6}-10^{-4}\right)$. This study revealed that although the concentration of heavy metal(loid)s in ground dust and linked health risk in the IZS area has reduced dramatically after the cessation of IZS, continued removal of slag residues and smelting potteries is necessary for further decreasing the human health risk.
\end{abstract}

Keywords: zinc smelting activities; ground dust; contamination level; exposure risks; temporal changes

\section{Introduction}

Heavy metal(loid)s could induce a serial of adverse effects on human beings and animals and deteriorate the environment through natural and anthropogenic activities [1-4]. Lead-zinc smelting is an important source of potentially toxic elements [5-7]. China ranked the largest $\mathrm{Zn} / \mathrm{Pb} / \mathrm{Cu}$ producer in the world for more than 20 years [8]. Besides the largescale smelting technique, small-scale or indigenous smelting had played an important role in the past decades in some areas of China, such as Sichuan, Yunnan, and Guizhou provinces in Southwest China [8-10]. Indigenous Zn smelting (IZS) in Northwestern 
Guizhou Province is more notable for its bigger scale and duration than other provinces due to the abundance of zinc and coal resources in this area and the increasing domestic demands [11]. The local IZS last for several centuries and the number of the IZS sites peaked in the 1980s and 1990s, when an output of Zn ingot reached more than $100 \mathrm{kt} / \mathrm{yr}$ [12]. Specially, a simple pyrometallurgy technique was employed during the IZS activities, in which coal was used as a fuel and reducing agent with poor pollution control measures. Consequently, the recovery of zinc resources during the IZS process was low $(50-60 \%$, [9]) but with relatively higher atmospheric emission factors for other metal(loid)s, such as $\mathrm{Pb}, \mathrm{Cd}, \mathrm{Hg}$, and $\mathrm{As}[10,13,14]$. The average $\mathrm{Hg}$ emission factors are 155 and $79 \mathrm{~g} \mathrm{Hg}$ per ton of $\mathrm{Zn}$ produced from sulfide and oxide ores, with $\mathrm{Cd}$ emission factors reaching up to 1460 and $1240 \mathrm{~g} \mathrm{Cd} \mathrm{t}^{-1}$, respectively [11,15]. In addition, massive sterile wastes and tailings $\left(2.1 \times 10^{7} \mathrm{t}\right)$ were produced and discarded locally during the IZS activities, which occupied $1200 \mathrm{hm}^{2}$ of area [16]. More importantly, high levels of toxic metals in the discarded slags were readily transported into the environment through natural weathering and other processes under low $\mathrm{pH}$ conditions [17,18]. Previous observation showed that a large amount wastewater containing 2.23 tons of $\mathrm{Pb}$ and $61 \mathrm{~kg}$ of $\mathrm{Cd}$ have resulted in serious $\mathrm{Pb} / \mathrm{Cd}$ contamination to local stream rivers in Northwestern Guizhou, China [19]. The death of fish and shrimp within dozens of kilometers from the IZS site have been attributed to the $\mathrm{Pb} / \mathrm{Cd}$ poisoning of heavy metal-contaminated water [19]. Local vegetables, crops, and even the traditional Chinese medical plants were also toxic metal(loid)s-contaminated in the IZS areas, hence, this activity contaminated the environment and posed a potential threat to residents $[10,20]$.

The IZS involved a lot of villagers from 1980s to 2000s since it was a high-income business at that time and the smelting sites were often close to or inside the villages (Figures 1 and 2), where the smelting furnaces were set up, where coal and zinc concentrate from the same county was transported to, and where zinc ingots were produced and the smelting slags were produced and thereby discarded (Figure 1). After the complete banning of IZS in 2006, the vast majority of smelting slag piles had not been treated for the first several years until 2010s when they were disposed of or landfilled by the local authorities to isolate these hazardous materials from the surface ecosystem (Figure 1). However, the smelting tool for holding the zinc concentrate (mortars) during smelting was still widely distributed in the village in the following years, being used for fences, walls, or as a weight (Figure 3).

To date, the heavy metal contamination in ground dust of these smelting villages or areas and the associated health risks in the IZS areas have not drawn much attention, and there is little information available concerning these two important aspects. Ground dust is a comprehensive indicator of pollution levels and is believed to present a higher pollution level in mining/smelting areas; thus, the effects of heavy metals in ground dust on human health cannot be ignored. The consensus is that the ingestion of dust particles appears to be the main route of heavy metal exposure to residents. More importantly, children are more vulnerable because of hand-to-mouth behavior, proximity to the floor, and different metabolisms when compared to adults [21-23].

Although the IZS activities in Northwestern Guizhou Province were terminated in 2006, high levels of $\mathrm{Pb}$ (mean \pm standard deviation (SD): $3510 \pm 4690 \mathrm{mg} \mathrm{kg}^{-1}$, range: 6-19,400 mg kg${ }^{-1}$ ), Zn (mean \pm SD: $6520 \pm 8260 \mathrm{mg} \mathrm{kg}^{-1}$, range: 5-36,500 $\mathrm{mg} \mathrm{kg}^{-1}$ ), Cd (mean \pm SD: $13.3 \pm 12.1 \mathrm{mg} \mathrm{kg}^{-1}$, range: $0.04-53.7 \mathrm{mg} \mathrm{kg}^{-1}$ ), and As (mean \pm SD: $169 \pm 290 \mathrm{mg} \mathrm{kg}^{-1}$, range: $3-1320 \mathrm{mg} \mathrm{kg}^{-1}$ ) in soil were observed by other researchers 10 years after the cessation of IZS activities [24]. As an important environmental media, ground dust has not been studied and reported for the heavy metal contamination, and the impact on human health is unclear. To fill these research gaps, a typical former IZS area located in Hezhang county, Northwestern Guizhou Province, China was selected; Guiyang city (the capital of Guizhou Province) was chosen as a control site. Ground dust samples both from IZS site and control site were collected in 2008 and 2018 for heavy metals analysis. The primary objectives of this study are (1) to investigate the long-term temporal variations 
of heavy metal(loid)s in ground dust of the IZS area, and (2) to evaluate the contamination status of these elements in the IZS area and related health risks to the local residents who were co-exposed to multiple heavy metal(loid)s. The results of this study will provide environmental managers with critical information for assessing the local environmental quality and taking necessary actions to further remediate the contamination in ground dust in these areas.
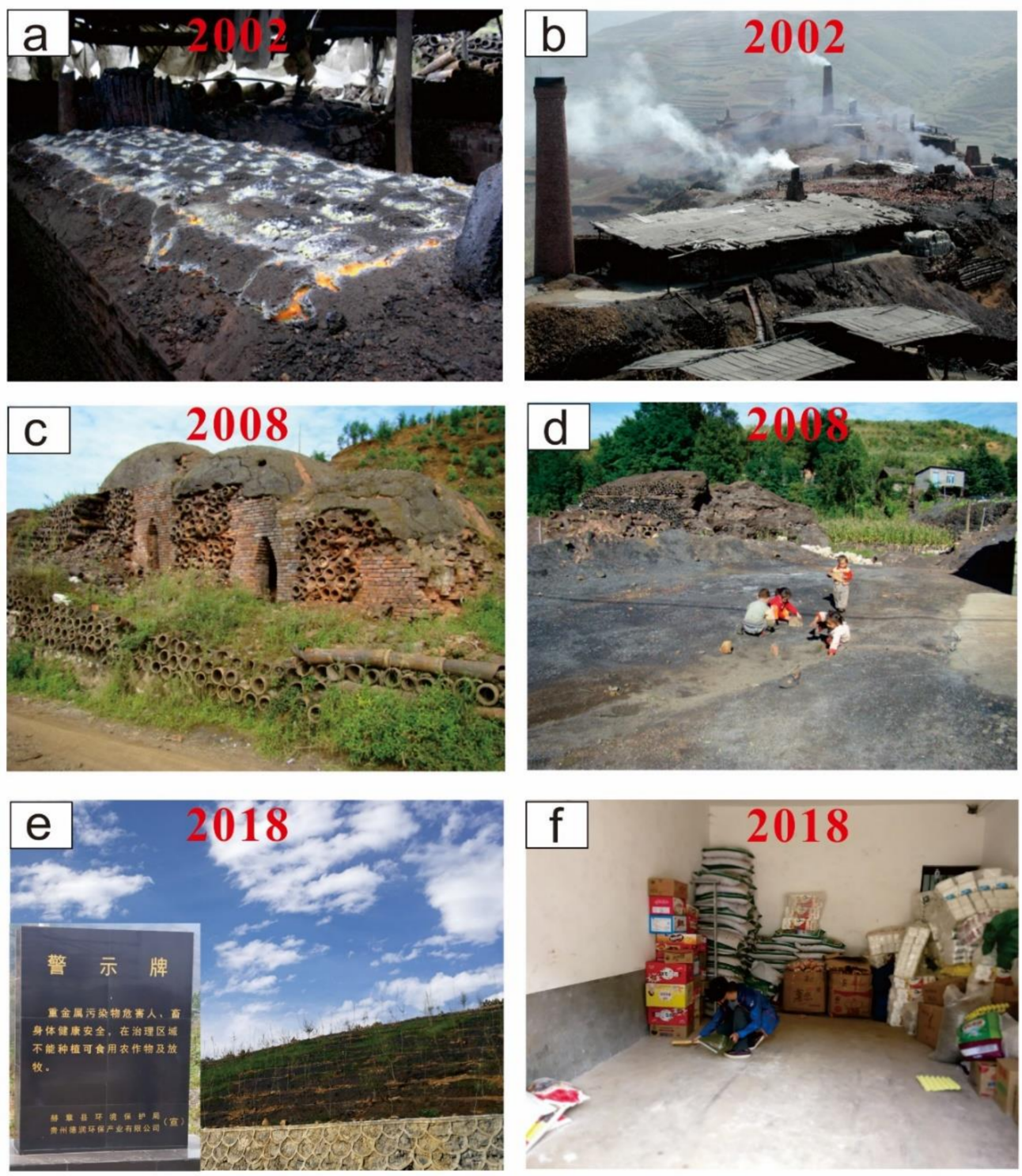

Figure 1. Dynamics of the indigenous zinc smelting (IZS) in Hezhang, Guizhou. (a and b, IZS activities in Hezhang before 2006; c and d, closed IZS furnace and slag piles in 2008 two years after the complete ceasing of IZS; e, Disposed zinc smelting slags after the 2010s; and f, ground dust collection in residential houses in 2018). 


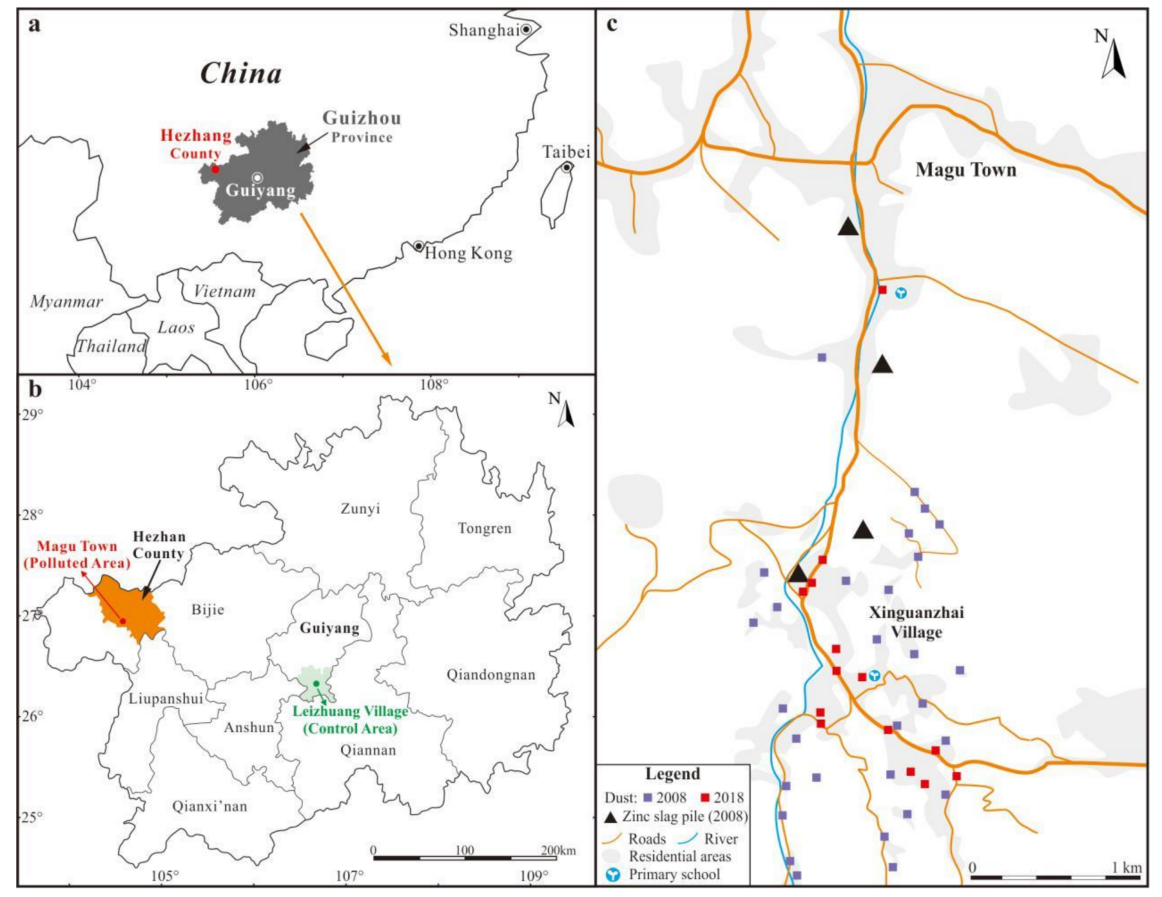

Figure 2. Relative location of the study areas in (a) China and (b) Guizhou, and (c) the detailed sampling sites in the IZS area.

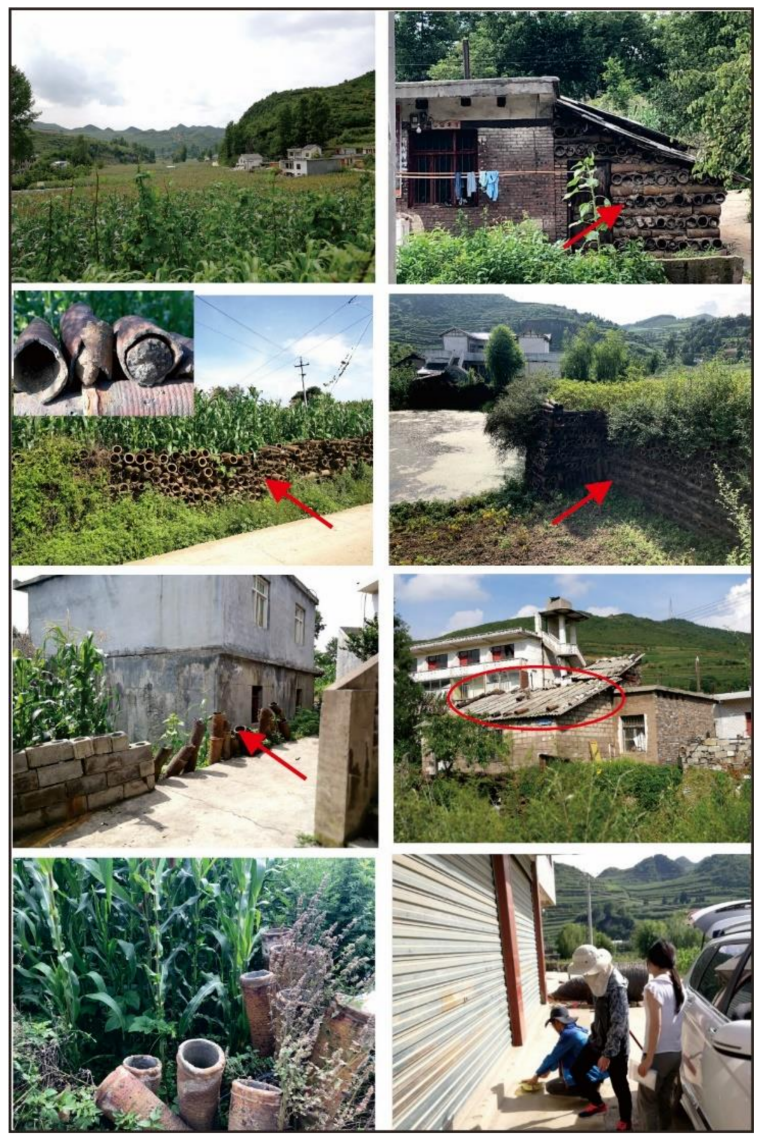

Figure 3. Legacy smelting pottery in Xin-Guan-Zhai village in 2018 and the on-site dust sampling. 


\section{Materials and Methods}

\subsection{Study Area and Sample Collection}

The historical IZS activities in Magu town of Hezhang county can be dated back to 10th century (947 AD), and the IZS activities appeared in its heyday during the period from 1980s to early 2000s (Figure 1a,b), with more than 520 "Macao local small furnaces" distributed in this area [12]. Magu town was known in China for its contribution to the environmental contamination/destruction. Xin-Guan-Zhai village is recognized as a typical IZS area close to Magu town $(<5 \mathrm{~km})$; the abandoned furnaces and large quantities of smelting slag were deposited along the village road after the secession of IZS in 2006 (Figure 1c,d). The IZS activities in Xin-Guan-Zhai village have resulted in serious heavy metal contamination (e.g., $\mathrm{Cd}, \mathrm{Zn}, \mathrm{Pb}$ ) to ambient soils, sediments, and agricultural crops [25] through the discharge of flue gas and slags (Figure 1a,b).

In this study, Xin-Guan-Zhai village was selected as the zinc smelting impacted area (Figures 1 and 2) and Leizhuang village in suburb Guiyang was selected as the control site, which experiences a similar climate in comparison to the Xin-Guan-Zhai village (IZS area) but has no IZS or other direct heavy metal point contamination sources. The control site of Leizhuang is located in the southwest of Guiyang city, the capital of Guizhou province, $\sim 35 \mathrm{~km}$ away from the city center and $\sim 300 \mathrm{~km}$ away from the IZS area. Magu town experiences a subtropical monsoon climate with an average annual rainfall of $900 \mathrm{~mm}$ and an annual average temperature of $12.5^{\circ} \mathrm{C}$. The total area of Magu town is $141.93 \mathrm{~km}^{2}$, with a lowest and highest elevation of $1775 \mathrm{~m}$ and $2588 \mathrm{~m}$, respectively. Corn is the predominant agricultural crop in the study area, which accounts for $45-55 \%$ of the total annual production, followed by rice, potatoes, wheat, and soybeans.

In this study, thirty-seven and fourteen ground dust samples were randomly collected from the whole Xin-Guan-Zhai village in Sep. 2008 and July 2018, respectively, to disclose the overall contamination of this village, since the whole village was involved in the IZS, with smelting furnaces and slag piles having been concentrated in the north part of village (Figure 2). This village is located in a valley surrounded by small hills $(<200 \mathrm{~m}$ in height) and a small stream that flows away (Figures 2 and 3). Furthermore, fifteen ground dust samples were collected from the control site of Leizhuang village in Sep. 2008 (Figure 2). No samples were collected in the control area in 2018 since there was no industrial activities and the living conditions of local residents did not change too much during the study period, hence the levels of heavy metals in ground dust were assumed to be similar to that in 2008. In detail, ground dust samples (30-100 $\mathrm{g}$ for each of the sampling site) were collected with a clean plastic dustpan and a brush from the village roads (mostly unpaved roads in 2008 and paved roads in 2018), residential yards (mainly paved), and living rooms within an area of $5-10 \mathrm{~m}^{2}$. All dust samples were collected by hand with a disposable polyethylene glove and stored in polyethylene bags to avoid cross contamination before being brought back to the laboratory and finally air-dried. The stone, glass, and cigarette butts were removed, and the samples were then ground with an agate mortar and sieved through 100 mesh $(0.15 \mathrm{~mm})$ nylon sieves; only the portion lesser than $0.15 \mathrm{~mm}$ was subjected for heavy metal(loid)s analysis.

\subsection{Analytical Methods for Hery Metal(loid)s}

A total of 15 elements, including silver (Ag), arsenic (As), bismuth (Bi), cadmium $(\mathrm{Cd})$, cobalt $(\mathrm{Co})$, chromium $(\mathrm{Cr})$, copper $(\mathrm{Cu})$, mercury $(\mathrm{Hg})$, indium $(\mathrm{In})$, nickel $(\mathrm{Ni})$, lead $(\mathrm{Pb})$, antimony $(\mathrm{Sb})$, tin $(\mathrm{Sn})$, thallium $(\mathrm{Tl})$, and zinc $(\mathrm{Zn})$, were analyzed in the dust samples. Total $\mathrm{Hg}$ content in dust samples was measured using a Milestone ${ }^{\mathrm{TM}}$ direct mercury analyzer (Model DMA 80, AMA 254 Software) following USEPA method 7473 [26]. Arsenic was determined using atomic fluorescence spectrometry (AFS-920, Beijing Jitian Instrument Corporation) after the sample was digested with $\mathrm{HNO}_{3}-\mathrm{HCl}-\mathrm{H}_{2} \mathrm{O}_{2}$ following USEPA method 3050B [27]. For the analysis of other thirteen elements, approximately $50 \mathrm{mg}$ of sample was transferred into a $10 \mathrm{~mL}$ Teflon digestion tank and digested with a freshly prepared mixture of $2 \mathrm{~mL}$ concentrated $\mathrm{HF} / \mathrm{HNO}_{3}(v / v, 1: 1)$. Then, the tank was 
tightly capped and heated in muffle $\left(190^{\circ} \mathrm{C}\right)$ for $24 \mathrm{~h}$. Once cooled down, the tank was uncapped and re-heated on a hot plate at $150^{\circ} \mathrm{C}$ to completely evaporate the digest. The digest was then evaporated to dryness after the addition of $0.5 \mathrm{~mL} \mathrm{HNO}_{3}$. Finally, $2 \mathrm{~mL}$ $\mathrm{HNO}_{3}, 2 \mathrm{~mL}$ deionized water, and $500 \mathrm{ng}$ of $\mathrm{Rh}$ (internal standard) were added into the digestion and heated for additional $5 \mathrm{~h}$ at $140{ }^{\circ} \mathrm{C}$ [28]. A suitable volume of aliquot from the digested sample was taken for trace heavy metal(loid)s analysis by inductively coupled plasma-mass spectrometer (ICP-MS, ELAN DRC-e, PerkinElmerSCIEX, Shelton, CT, USA).

\section{3. $Q A / Q C$ and Statistical Analysis}

Quality assurance and quality control $(\mathrm{QA} / \mathrm{QC})$ for elements analysis in the dust samples was conducted using method blanks, duplicates, and standard reference materials (non-contaminated soil GSS-5 and contaminated soil NIST 2710). The recoveries of the elements ranged from $90.6 \%$ to $107.2 \%$. The relative standard deviation for analysis of duplicate samples was less than $5 \%$.

Statistical analysis was performed using Excel 2019 and IBM SPSS Statistics 25 for Windows. One-way analysis variance (ANOVA) and independent-samples t test in SPSS were performed to compare significant differences between two independent datasets, e.g., between different areas (zinc smelting and control areas) or different periods (2008 and 2018). Significant differences between these average values are indicated by a $p$ value less than 0.05. The data were plotted using Origin Pro. 2018.

\subsection{Pollution Assessment Method}

The pollution status of a single element was assessed using the geo-accumulation index $\left(I_{g e o}\right)$ approach [29], which was popularly employed in previous study [30,31]. Igeo was calculated using Equation (1):

$$
\mathrm{I}_{\text {geo }}=\log _{2} \frac{\mathrm{C}_{\mathrm{n}}}{\mathrm{k} \times \mathrm{B}_{\mathrm{n}}} .
$$

where $C_{n}$ is the concentration of heavy metal(loid)s in dust (mg/kg); $B_{n}$ is the elemental geochemical background concentration $(\mathrm{mg} / \mathrm{kg})$. In this study, the soil background value in Guizhou Province was taken as a reference to eliminate the influence geological background [32]; $\mathrm{k}$ is a correction coefficient (typically 1.5) used to consider the variations in the background value caused by diagenesis. The standard classifications of $I_{\text {geo }}$ for heavy metals are divided into seven class, Class $0, I_{\text {geo }} \leq 0$, uncontaminated; Class $1,0<$ $I_{\text {geo }} \leq 1$, uncontaminated to moderately contaminated; Class $2,1<I_{\text {geo }} \leq 2$, moderately contaminated; Class 3, $2<I_{\text {geo }} \leq 3$, moderately to strongly contaminated; Class $4,3<I_{\text {geo }}$ $\leq 4$, strongly contaminated; Class $5,4<I_{\text {geo }} \leq 5$, strongly to extremely contaminated; Class $6, I_{\text {geo }} \geq 5$, extremely contaminated [29].

\subsection{Health Risk Assessment}

The ground dust can impact human health through ingestion, inhalation, and dermal contact $[33,34]$. Therefore, there are usually two methods to assess such health risks, with one of the bioaccessibility assessments simulating lung and gastric-intestinal fluids $[35,36]$ and one with exposure assessment models developed by the U.S. Environmental Protection Agency [37]. The latter method was used in this study, with three main routes of human exposure, including direct ingestion of substrate particles ( $\left.\mathrm{ADD}_{\mathrm{ing}}\right)$, inhalation of re-suspended particles through mouth and nose $\left(\mathrm{ADD}_{\mathrm{inh}}\right)$, and dermal absorption of trace elements in particles adhered to the exposed skin ( $\left.\mathrm{ADD}_{\text {dermal }}\right)$, being calculated using Equations (2)-(4). For $\mathrm{Hg}$, exposure via inhalation of its elemental vapor was evaluated using Equation (5). For carcinogens, the lifetime average daily dose (LADD) was used for cancer risk assessment and calculated as a weighted average for each exposure route (Equation (6)):

$$
\mathrm{ADD}_{\text {ing }}=\frac{\mathrm{C} \times \mathrm{EF} \times \mathrm{ED} \times \operatorname{IngR} \times 10^{-6}}{\mathrm{AT} \times \mathrm{BW}} .
$$




$$
\begin{gathered}
\mathrm{ADD}_{\text {inh }}=\frac{\mathrm{C} \times \mathrm{EF} \times \mathrm{ED}}{\mathrm{AT} \times \mathrm{BW}} \times \frac{\mathrm{InhR}}{\mathrm{PEF}} . \\
\mathrm{ADD}_{\text {dermal }}=\frac{\mathrm{C} \times \mathrm{EF} \times \mathrm{ED} \times \mathrm{SL} \times \mathrm{SA} \times \mathrm{ABS} \times 10^{-6}}{\mathrm{AT} \times \mathrm{BW}} . \\
\mathrm{ADD}_{\text {vapour }}=\frac{\mathrm{C} \times \mathrm{InhR} \times \mathrm{EF} \times \mathrm{ED}}{\mathrm{VF} \times \mathrm{BW} \times \mathrm{AT}} . \\
\mathrm{LADD}=\frac{\mathrm{C} \times \mathrm{EF} \times \mathrm{ED} \times \mathrm{CR}}{\mathrm{AT} \times \mathrm{BW} \times \mathrm{PEF}} .
\end{gathered}
$$

where $\mathrm{C}$ is the concentration of heavy metal (loid) in the ground dust; $\mathrm{EF}$ is the exposure frequency; $\mathrm{ED}$ is exposure duration; $\mathrm{IngR}$ and $\mathrm{InhR}$ is the ingestion and inhalation rate, respectively; $\mathrm{AT}$ is the averaging time; $\mathrm{BW}$ is the average body weight; $\mathrm{PEF}$ is particle emission factor; SL is the skin adherence factor; $\mathrm{SA}$ is the exposed skin area; $\mathrm{ABS}$ is dermal absorption factor (unitless); $\mathrm{VF}$ is the volatilization factor; $\mathrm{CR}$ is contact (absorption) rate. The details of these parameters are listed in Table S1 in the supporting information. Considering that the concentration of each trace element followed the log-normal distribution, the $95 \%$ upper confidence limit (UCL) was calculated using the statistical software SPSS.

The potential non-carcinogenic and carcinogenic risks for humans were calculated using Equations (7) and (8) [38].

$$
\begin{gathered}
H I=\sum H Q_{i}=\sum \frac{A D D_{i j}}{\operatorname{RfD}_{i j}} . \\
R_{i}=L_{A D D} \times S_{i j} .
\end{gathered}
$$

where $\mathrm{HI}$ is the hazard index and represents total non-carcinogenic risk, which equals to the sum of the $\mathrm{HQ}$ values; $\mathrm{HQ}_{\mathrm{i}}$ is the risk associated with non-carcinogenic heavy metal $\mathrm{i} ; \mathrm{ADD}_{\mathrm{ij}}$ is the average daily exposure to non-carcinogenic heavy metal $\mathrm{i}$ through $\mathrm{j}$ exposure routes $\left(\mathrm{mg} \cdot \mathrm{kg}^{-1} \cdot \mathrm{day}^{-1}\right)$; $\mathrm{RfD}_{\mathrm{ij}}$ is the reference dose $\left(\mathrm{mg} \cdot \mathrm{kg}^{-1} \cdot \mathrm{day}^{-1}\right) ; \mathrm{R}_{\mathrm{i}}$ is the risk associated with carcinogenic heavy metal $\mathrm{i} ; \mathrm{LADD}_{\mathrm{ij}}$ is the average end-life exposure to carcinogenic heavy metal $\mathrm{i}$ through $\mathrm{j}$ exposure routes $\left(\mathrm{mg} \cdot \mathrm{kg}^{-1} \cdot \mathrm{day}^{-1}\right) ; \mathrm{SF}_{\mathrm{ij}}$ is the slope factor of carcinogenic heavy metal i $\left(\mathrm{kg} \cdot\right.$ day $\left.\cdot \mathrm{mg}^{-1}\right)$. Reference dose and carcinogenic slope factor values for different exposure routes of heavy metal(loid)s are shown in Table S2. If the value of $\mathrm{HI}$ is less than one, it is assumed that there is no significant risk of non-carcinogenic effects. If HI exceeds one, then there is a chance that non-carcinogenic effects occur, with a probability which tends to increase as the value of $\mathrm{HI}$ increases [37]. If carcinogenic risk $<1 \times 10^{-6}$, the carcinogenic risk is negligible; if carcinogenic risk $>1 \times 10^{-4}$, the risk of developing cancer becomes high; and if carcinogenic risk values remain within the range of $1 \times 10^{-6}$ and $1 \times 10^{-4}$, it is an acceptable or tolerable risk to social stability and human health [38].

\section{Results and Discussion}

\subsection{Concentrations of Heavy Metal(loid)s in Ground Dust}

Concentration of heavy metal(loid)s in ground dust collected from the IZS area and control sites are shown in Table 1; the large variation of most elements, especially in the IZS area, indicates a high skewness of data. The mean concentrations of different elements in ground dust from the IZS area collected in 2008 increased in the order of $\mathrm{Hg}, \mathrm{In}, \mathrm{Tl}$, $\mathrm{Ag}, \mathrm{Bi}, \mathrm{Sb}, \mathrm{Sn}, \mathrm{Co}, \mathrm{Cd}, \mathrm{Ni}, \mathrm{Cr}, \mathrm{As}, \mathrm{Cu}, \mathrm{Pb}$, and $\mathrm{Zn}$, and with the order of $\mathrm{Hg}, \mathrm{Tl}, \mathrm{In}, \mathrm{Ag}$, $\mathrm{Bi}, \mathrm{Cd}, \mathrm{Sn}, \mathrm{Sb}, \mathrm{Co}, \mathrm{As}, \mathrm{Ni}, \mathrm{Cr}, \mathrm{Cu}, \mathrm{Pb}$, and $\mathrm{Zn}$ in 2018. Although the sequence of element abundance is slightly different between 2008 and 2018, $\mathrm{Zn}$ and Pb were confirmed as the most abundant elements. In 2008, $\mathrm{Zn}$ and $\mathrm{Pb}$ in the dust of IZS area ranged from 256 to $8245 \mathrm{mg} / \mathrm{kg}$ and 220 to $6348 \mathrm{mg} / \mathrm{kg}$, respectively. The average values of $\mathrm{Zn}$ and $\mathrm{Pb}$ in dust samples from IZS area were more than 38 and 70 times of Guizhou soil background ( $89.94 \mathrm{mg} / \mathrm{kg}$ for $\mathrm{Zn}, 29.39 \mathrm{mg} / \mathrm{kg}$ for Pb, [32]), indicating extreme enrichment. In 2018, the concentrations of $\mathrm{Zn}$ and $\mathrm{Pb}$ ranged from 448 to $2849 \mathrm{mg} / \mathrm{kg}$ and from 169 to $1974 \mathrm{mg} / \mathrm{kg}$, 
respectively. The mean concentrations of $\mathrm{Zn}(1287 \mathrm{mg} / \mathrm{kg})$ and $\mathrm{Pb}(762 \mathrm{mg} / \mathrm{kg})$ in 2018 decreased by more than $60 \%$ compared to those in 2008 , however, these values obtained after ceasing the IZS activities 12 years were still 14 and 26 times higher than the soil background values in Guizhou Province. Studies have shown that the anthropogenic enrichment of zinc and lead in urban samples has reached a medium level, indicating the contribution of traffic emissions [39]. For this study area, the excess accumulation of lead and zinc in dust is mainly attributed to industrial activities. The serious contamination of $\mathrm{Zn}$ and $\mathrm{Pb}$ in ground dust can be attributed to the improper treatment of mortars which is a pottery holding $\mathrm{Zn}$ concentrate and has been used as a smelting tool for IZS and now is used for fences, walls, and other uses by local people (Figure 3). In addition, the polluted local soils surrounding the dwelling houses would be another source of heavy metal(loid)s in dust [24], since plenty of activities, e.g., the soil tillage, wind erosion, and walking, could bring the contaminated soil into the ground dust [40]. Average concentrations of other metal(loid)s (Ag, As, Cd, Cu, Sb, and $\mathrm{Sn}$ ) in ground dust decreased by $44 \%, 62 \%$, $70 \%, 74 \%, 45 \%$, and $58 \%$ at the IZS area during the period from 2008 to 2018 , respectively (Table 1). Furthermore, the average concentrations of these elements in 2018 were 5.06, $2.81,24.78,3.29,8.07$, and 2.69 times when compared to the background soil in Guizhou Province [32], respectively. Differently, concentrations of $\mathrm{Bi}, \mathrm{Co}, \mathrm{Cr}, \mathrm{Hg}$, In, $\mathrm{Ni}$, and $\mathrm{Tl}$ in the dust samples from the IZS area remained almost unchanged over the period of 2008-2018. High concentrations of heavy metal(loid)s in the dust samples of the IZS area in 2008 resulted from the waste residue piles since most of them were not properly treated (Figure 1d). In 2018, high values of $\mathrm{Pb}, \mathrm{Zn}$, and $\mathrm{Cd}$ were detected in locations that had mortar as fences, and the lowest values of these elements were observed in newly built houses. In contrast to the soil heavy metal pollution in the IZS area that kept relative stable over time [24], heavy metal(loid)s contamination in ground dust had been greatly mitigated via the smoke reduction after the cessation of IZS activities and the treatment of smelting residues in 2010 s by blocking the source of heavy metal(loid)s.

Table 1. Concentrations of heavy metal(loid)s in ground dust of this study and the background values in agricultural soil in Guizhou and China (unit in $\mathrm{mg} / \mathrm{kg}$ ).

\begin{tabular}{|c|c|c|c|c|c|c|c|}
\hline \multirow{2}{*}{ Elements } & \multicolumn{3}{|c|}{ Range (Min-Max) } & \multicolumn{3}{|c|}{ Arithmetic Mean (Mean \pm SD) } & \multirow{2}{*}{$\begin{array}{c}\text { Background } \\
\text { Soils in } \\
\text { Guizhou }\end{array}$} \\
\hline & $\begin{array}{l}\text { IZS Area } \\
2008\end{array}$ & $\begin{array}{c}\text { IZS Area } \\
2018\end{array}$ & $\begin{array}{c}\text { Control Area } \\
2008\end{array}$ & $\begin{array}{l}\text { IZS Area } \\
2008\end{array}$ & $\begin{array}{c}\text { IZS Area } \\
2018\end{array}$ & $\begin{array}{c}\text { Control Area } \\
2008\end{array}$ & \\
\hline $\mathrm{Ag}$ & $0.37-7.98$ & $0.47-4.25$ & $0.23-0.36$ & $2.80 \pm 2.08$ & $1.57 \pm 1.13$ & $0.31 \pm 0.04$ & 0.068 \\
\hline As & $4.2-390.2$ & $13.6-135.9$ & $4.9-25.9$ & $111.0 \pm 96.0$ & $41.9 \pm 34.8$ & $13.8 \pm 5.2$ & 14.89 \\
\hline $\mathrm{Bi}$ & $0.31-12.29$ & $0.63-20.80$ & $0.47-1.17$ & $3.66 \pm 3.16$ & $3.87 \pm 5.39$ & $0.70 \pm 0.21$ & 0.41 \\
\hline $\mathrm{Cd}$ & $2.19-124.22$ & $3.01-22.63$ & $0.17-2.32$ & $25.62 \pm 21.93$ & $7.76 \pm 5.06$ & $0.78 \pm 0.61$ & 0.313 \\
\hline Co & $4-42$ & $10-26$ & $11-24$ & $25 \pm 9$ & $18 \pm 5$ & $17 \pm 3$ & 17.38 \\
\hline $\mathrm{Cr}$ & $32-195$ & $55-179$ & $53-109$ & $104 \pm 36$ & $96 \pm 33$ & $76 \pm 17$ & 79.42 \\
\hline $\mathrm{Cu}$ & 49-2442 & $35-216$ & $65-3636$ & $371 \pm 413$ & $97 \pm 46$ & $672 \pm 1062$ & 29.43 \\
\hline $\mathrm{Hg}$ & $0.09-6.80$ & $0.11-1.12$ & $0.16-3.95$ & $0.51 \pm 1.08$ & $0.32 \pm 0.33$ & $0.57 \pm 0.95$ & 0.103 \\
\hline In & $0.04-2.78$ & $0.10-2.28$ & $0.06-0.14$ & $0.60 \pm 0.53$ & $0.51 \pm 0.57$ & $0.09 \pm 0.02$ & 0.102 \\
\hline $\mathrm{Ni}$ & $11-143$ & 23-61 & $31-64$ & $67 \pm 32$ & $44 \pm 10$ & $41 \pm 10$ & 32.84 \\
\hline $\mathrm{Pb}$ & $220-6348$ & 168-1974 & $40-163$ & $2065 \pm 1710$ & $762 \pm 647$ & $78 \pm 33$ & 29.39 \\
\hline $\mathrm{Sb}$ & $1.7-64.8$ & $3.8-32.5$ & 1.3-9.1 & $19.7 \pm 14.3$ & $10.9 \pm 7.4$ & $2.8 \pm 2.0$ & 1.35 \\
\hline Sn & $1.98-126.48$ & $3.10-25.64$ & $2.61-6.90$ & $20.37 \pm 21.73$ & $8.57 \pm 5.46$ & $3.98 \pm 1.43$ & 3.19 \\
\hline $\mathrm{Tl}$ & $0.13-2.16$ & $0.24-0.74$ & $0.20-0.83$ & $0.87 \pm 0.44$ & $0.42 \pm 0.14$ & $0.43 \pm 0.13$ & 0.712 \\
\hline $\mathrm{Zn}$ & $256-8245$ & $448-2848$ & $123-569$ & $3488 \pm 2526$ & $1287 \pm 753$ & $295 \pm 149$ & 89.94 \\
\hline
\end{tabular}

Note: IZS area, artisanal zinc smelting area; Mean: arithmetic average; SD, standard deviation; Min, minimum; Max, maximum; Guizhou and China, background in surface soil $(0-20 \mathrm{~cm}$ ) of Guizhou (Soil Background Value in Guizhou Province) and China (National Background Value of Soil (Layer A)), respectively. Sample number for IZS area 2008, IZS area 2018 and control area 2008 is 37, 14, and 15, respectively.

Compared with the control area (Table 1), nine elements ( $\mathrm{Ag}, \mathrm{As}, \mathrm{Bi}, \mathrm{Cd}, \mathrm{In}, \mathrm{Pb}$, $\mathrm{Sb}, \mathrm{Sn}, \mathrm{Zn}$ ) in the IZS area in 2008 and 2018 had elevated concentrations, indicating the impact of IZS on the accumulation of metal(loid)s in local ground dust. No significant differences were observed between the IZS sites and the control sites for $\mathrm{Co}, \mathrm{Cr}, \mathrm{Hg}, \mathrm{Ni}$, 
and $\mathrm{Tl}$ concentrations, which can be explained by several reasons. Firstly, $\mathrm{Co}, \mathrm{Cr}$, and $\mathrm{Ni}$ are not associated with $\mathrm{Zn}$ ores [41]; secondly, $\mathrm{Hg}$ emitted in the flue gas with depletion in the residues [15]; thirdly, much lower $\mathrm{Tl}$ concentrations $(<1 \mathrm{mg} / \mathrm{kg})$ were observed in the local Zn ore [42] than those used in other Zn smelters in China (Tl: 15-88 mg/kg) [43]. On the contrary, $\mathrm{Cu}$ was remarkably higher in the control area than the IZS area, likely because of the common use of copper-containing products, devices, or wires. In addition, the concentration of $\mathrm{Cu}$ is related to traffic emissions [44].

The results suggested that the concentrations of over a half element $(\mathrm{Zn}, \mathrm{Pb}, \mathrm{Cu}, \mathrm{Cd}$, $\mathrm{Ag}, \mathrm{As}, \mathrm{Sn}$, and $\mathrm{Sb}$ ) in dust samples were linked to the IZS activities since the significantly decreased values in 2018 were compared to those in 2008 (Table 1). A similar trend was observed in Avilés [45], an industrial area in Spain, where some industrial activities have declined, with concentrations of $\mathrm{Zn}, \mathrm{Cd}, \mathrm{Hg}, \mathrm{Ag}$, and $\mathrm{As}$ in ground dust decreasing over time (1996-2001, 2001-2006) in four surveys (1996, 2001, 2006, 2011). Although zinc smelting has been banned for many years in the study area, its impact last a long time, as shown by the excess background values in varying degrees in the following ascending order: Tl, Sn, As, Hg, Cu, In, Sb, Bi, Ag, Cd, Zn, Pb. High concentrations of $\mathrm{Zn}, \mathrm{Cd}$, and Pb were also observed in the street dust in Huludao City that was impacted by the large-scale Zn smelting activities [22].

In this study, the concentrations of heavy metals in dust samples from the IZS area were at the same levels when compared to other cities that were influenced by large-scale $\mathrm{Pb} / \mathrm{Zn}$ smelting activities, such as Zhuzhou [41] and Huludao [21] in China, and Avilés in Spain [5,45]. However, heavy metal concentrations in dust samples from the IZS area were much higher than those of other locations with an absence of non-ferrous smelting activities (Table 2). Even in 2018, the concentrations of most heavy metal(loid)s, such as As, $\mathrm{Cd}, \mathrm{Pb}$, and $\mathrm{Zn}$, in ground dust at the IZS sites were approximately ten times higher than those in other non-smelting cities, indicating the ongoing severity of contamination in the study area.

Table 2. Comparison of mean values of heavy metal(loid)s in ground dust of different sites (unit in $\mathrm{mg} / \mathrm{kg}$ ).

\begin{tabular}{|c|c|c|c|c|c|c|c|c|c|c|c|c|c|c|c|c|}
\hline Study Site & Ag & As & Bi & $\mathrm{Cd}$ & Co & $\mathrm{Cr}$ & $\mathrm{Cu}$ & $\mathrm{Hg}$ & In & $\mathrm{Ni}$ & $\mathrm{Pb}$ & $\mathrm{Sb}$ & Sn & Tl & $\mathrm{Zn}$ & Reference \\
\hline IZS area 2008 & 2.80 & 111 & 3.66 & 25.6 & 25 & 104 & 371 & 0.51 & 0.60 & 67 & 2065 & 19.7 & 20.37 & 0.87 & 3488 & This study \\
\hline IZS area 2018 & 1.57 & 41.9 & 3.87 & 7.76 & 18 & 96 & 97 & 0.32 & 0.51 & 44 & 762 & 10.9 & 8.57 & 0.42 & 1287 & This study \\
\hline Control area 2008 & 0.31 & 13.8 & 0.70 & 0.78 & 17 & 76 & 672 & 0.57 & 0.09 & 41 & 78 & 2.8 & 3.98 & 0.43 & 295 & This study \\
\hline Hezhang city, China & 0.68 & 55.9 & 0.86 & 6.45 & 17.5 & 133 & 153 & 0.27 & 0.21 & 40.6 & 409 & 7.44 & 7.34 & 0.27 & 966 & [46] \\
\hline Zhuzhou city, China & 2.49 & 89 & 12.3 & 41.4 & 13 & 125 & 139 & 0.92 & 4.06 & 40 & 956 & 15.8 & & 1.08 & 2379 & [41] \\
\hline Huludao city, China & & & & 72.8 & & & 264 & 1.22 & & & 533 & & & & 5271 & [21] \\
\hline Avilés city, Spain & 3.76 & 37.6 & & 45.1 & 10.9 & 109 & 370 & 2.93 & & 43.3. & 496 & 10.4 & & & 12,036 & [45] \\
\hline Guiyang city, China & & 11.28 & & 0.62 & & 131 & 130 & 0.33 & & 61 & 67.8 & & & & 186 & [47] \\
\hline Beijing city, China & & 4.88 & & 0.59 & & 92 & 83.1 & 0.16 & & 32.5 & 60.9 & & & & 281 & [48] \\
\hline Shanghai city, China & & & & 1.23 & & 159 & 197 & & & 84.0 & 295 & & & & 734 & [49] \\
\hline Hongkong, China & & & & 3.77 & & & 173 & & & & 181 & & & & 1450 & [50] \\
\hline Egypt & & 6.53 & & 2.98 & & 85.7 & 102 & & & 38.5 & 307 & & 12.4 & & 1839 & [51] \\
\hline Shiraz, Iran & & 6.58 & & 0.5 & & 67.2 & 136 & 1.05 & & 77.52 & 116 & & & & 403 & [52] \\
\hline Toronto, Canada & & & & 0.51 & & 197.9 & 162 & & & 58.8 & 182.8 & & & & 232.8 & [53] \\
\hline
\end{tabular}

\subsection{Contamination Degree of Heavy Metal(loid)s in Ground Dust}

The average contamination degree of ground dust in the IZS area and control site is listed in Table S3. The comparison of the geo-accumulation index of each element in dust samples during the period of 2008 to 2018 is shown in Figure 4. The geo-accumulation index of most elements in dust from the IZS area in 2018 was lower than that in 2008. For samples collected in 2008, the average $I_{\text {geo }}$ value of $\mathrm{Co}, \mathrm{Cr}$, and $\mathrm{Tl}$ was less than 0 (uncontaminated), with the corresponding values higher than 0 for other elements, indicating different accumulation levels between the two-group elements. Most elements had $I_{\text {geo }}>2$ : Sb (2.88), Cu (2.55), Bi (2.02) $\left(2<I_{\text {geo }} \leq 3\right.$ : moderately to heavily contaminated), or even higher than 4, such as $\mathrm{Zn}$ (4.19), $\mathrm{Ag}$ (4.38), $\mathrm{Pb}(4.99)\left(4<I_{\text {geo }} \leq 5\right.$ : heavily to 
extremely contaminated), and $\mathrm{Cd}$ (5.36) ( $I_{\text {geo }} \geq 5$ : extremely contaminated), indicating the extra $\mathrm{Zn}, \mathrm{Ag}, \mathrm{Pb}$, and $\mathrm{Cd}$ accumulation in ground dust (Table $\mathrm{S} 3$ in Supporting Information). For the samples collected in 2018, clearly decreased $I_{\text {geo }}$ values for most elements were observed, while $I_{\text {geo }}$ values of $\mathrm{Zn}$ (3.00), $\mathrm{Pb}$ (3.60), Ag (3.64), and $\mathrm{Cd}$ (3.83) remained relatively higher $\left(3<I_{\text {geo }} \leq 4\right.$ : heavily contaminated). This is compared with the control area where the contamination levels of different elements were very low, with all $I_{\text {geo }}$ values lower than $1\left(0<I_{\text {geo }} \leq 1\right.$, uncontaminated to moderately contaminated), and some less than 0 (uncontaminated).

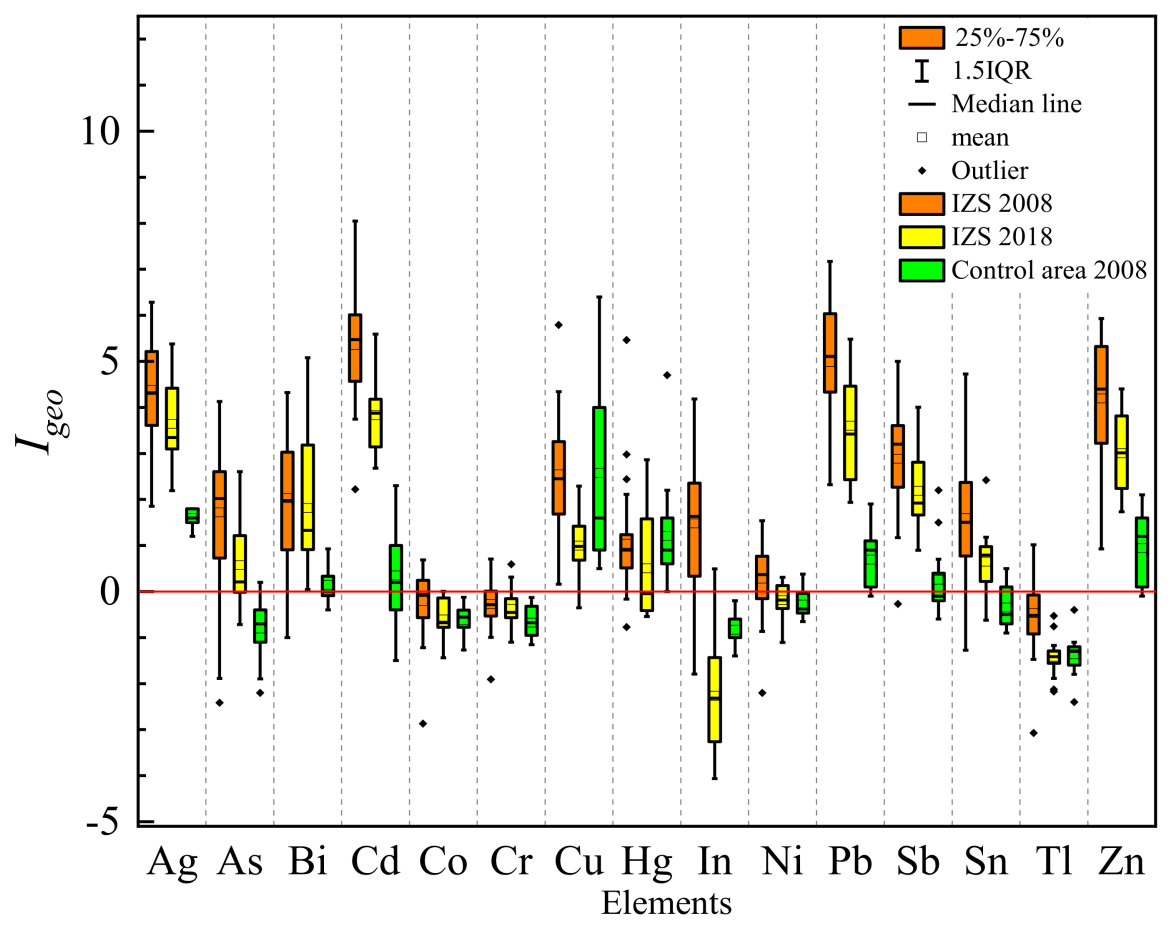

Figure 4. Heavy metal(loid) contamination of ground dust in this study revealed by $I_{\text {geo }}$ values (Note: 1.5IQR means 1.5 times quartile spacing).

\subsection{Human Health Risks of Heavy Metal(loid)s in Ground Dust}

\subsubsection{Non-Carcinogenic Risk to Residents}

The hazard index (HI) of non-carcinogenic risk of metal(loid)s in ground dust to residents is shown in Figure 5. The value of $\mathrm{HI}<1$ indicates a negligible non-carcinogenic risk to residents, whereas when $\mathrm{HI}>1$ there is a concern for non-carcinogenic health effects [37]. For adults, there was no risk of multiway exposure in both the IZS area and the control site (Figure 5a), whereas the situation for children was not optimistic (Figure 5b). In 2008, the $\mathrm{HI}$ values of $\mathrm{As}$ and $\mathrm{Pb}$ for children were 3.31 and 4.86, respectively (Table S4), with values far exceeding 1 . Despite the significantly decreasing heavy metals concentration in dust samples, the $\mathrm{HI}$ values of $\mathrm{As}$ and $\mathrm{Pb}$ in 2018 were still over the acceptable value (1.43 for As, 2.09 for $\mathrm{Pb}$ ) (Table S5), indicating that $\mathrm{As}$ and $\mathrm{Pb}$ posed non-carcinogenic health risks to children even a decade after the termination of IZS. Furthermore, the HI of children was 2-7 fold higher than that of the adults in most cases (Tables S4-S6), suggesting that children were more susceptible to similar exposure levels. This is due to the fact that children have frequent hand-to-mouth behavior, lower body weight, closer proximity to the floor and different metabolisms compared to adults. The contribution of different exposure routes was ranked as follows: ingestion $>$ dermal contact $>$ inhalation for both adults and children (Tables S4-S6). This sequence applies to all elements in this study with one exception $(\mathrm{Hg})$; the inhalation of $\mathrm{Hg}$ vapor was the principal exposure route instead of particulate matter, which agrees with the previous study [54]. The results demonstrated that $\mathrm{As}$ and $\mathrm{Pb}$ were the most important pollutants in ground dust of the IZS area that 
posed a non-carcinogenic health risk to residents, especially children. Thus, the potential health risks to children resulting from exposure to ground dust cannot be neglected.
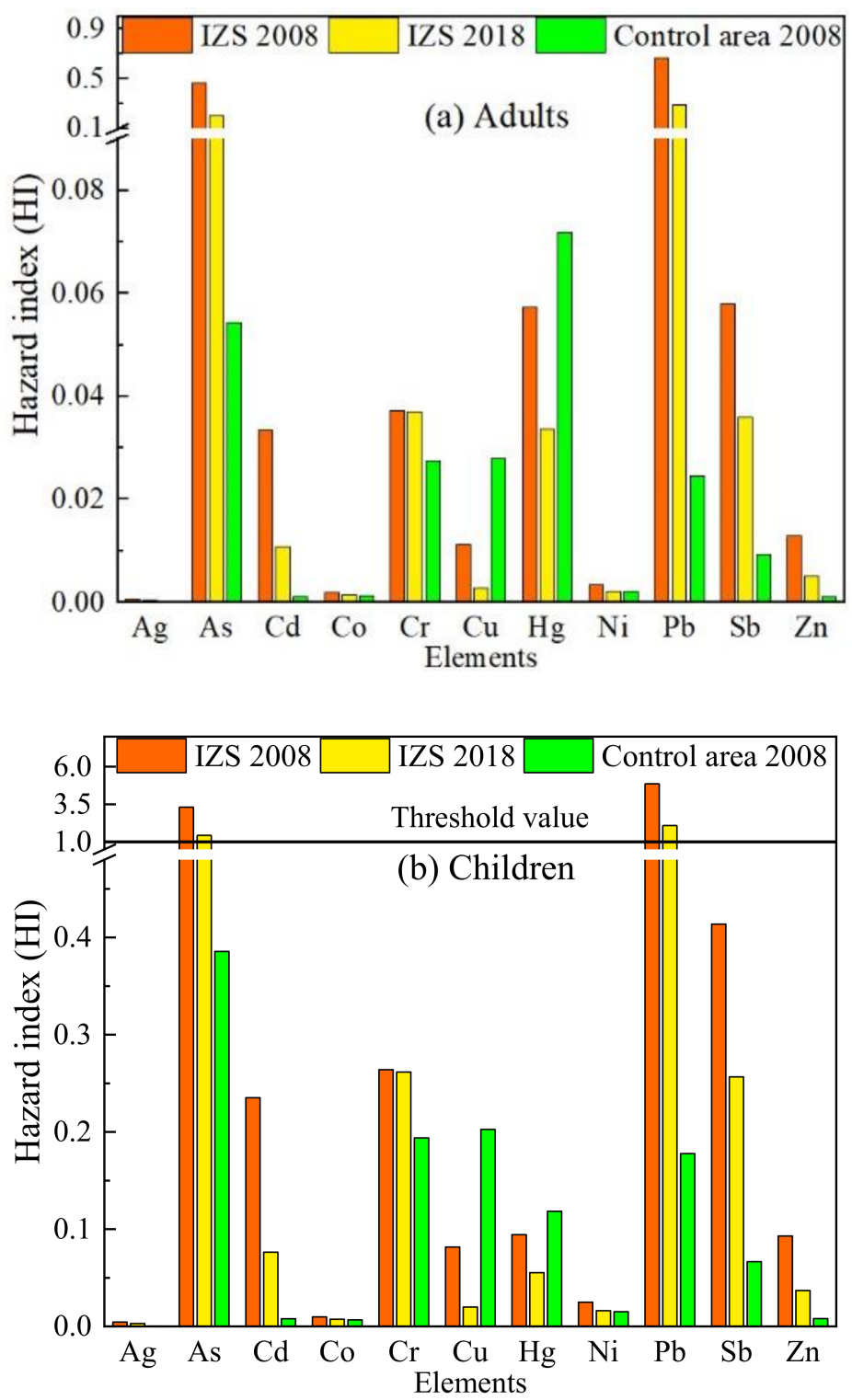

Figure 5. Hazard index (HI) of heavy metal(loid)s in ground dust to adults (a) and children (b).

\subsubsection{Carcinogenic Risk to Residents' Health}

Figure 6 shows the carcinogenic risk of exposure to $\mathrm{As}, \mathrm{Cd}, \mathrm{Co}, \mathrm{Cr}$, and $\mathrm{Ni}$ in ground dust. The corresponding data is listed in Table S7. The risk decreased in the following order: $\mathrm{As} \approx \mathrm{Cr}>>\mathrm{Co}>\mathrm{Cd}>\mathrm{Ni}$. For adults, the calculated risk for all these five elements did not exceed threshold value $\left(10^{-6}-10^{-4}\right)$ [55] in the IZS area both in 2008 and 2018. Although the levels of As and $\mathrm{Cr}$ for children were somewhat higher than those for adults, $\mathrm{Cr}$ was still in the acceptable value range. However, As represented the risk of $1.48 \times 10^{-6}$ in 2008, indicating an unacceptable carcinogenic risk. For both subpopulations, the carcinogenic risk of $\mathrm{Cd}$ and Co exposure $\left(10^{-8}-10^{-7}\right)$ fell below the threshold, and the risk of Ni exposure was within the lower range of $10^{-8}-10^{-9}$. It suggested that $\mathrm{Cd}, \mathrm{Co}$, and $\mathrm{Ni}$ exposure pose a negligible risk. Although there is an obvious disparity in the results for the IZS and the control area, the carcinogenic risk of exposure to five metals in ground dust was generally low, with As for children as an exception. 

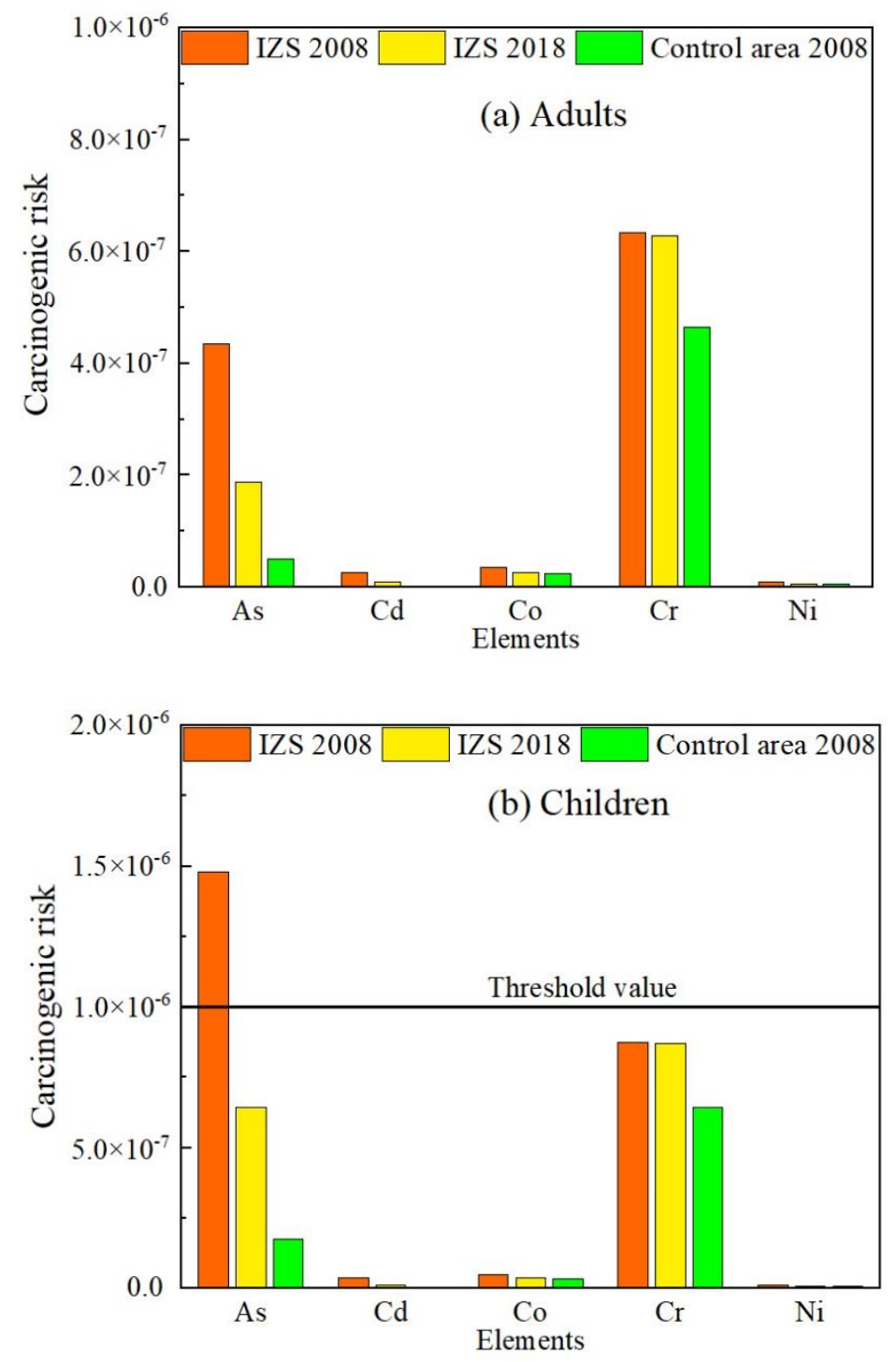

Figure 6. Carcinogenic risk of metal(loid)s in ground dust to adults (a) and children (b).

\section{Conclusions}

In this study, the dynamics of fifteen heavy metal(loid)s in ground dust at a former IZS area in Guizhou were tracked over 2008-2018 after the cessation of IZS in 2006. Over half of the elements (e.g., Ag, As, Cd, Cu, Pb, Sb, Sn, $\mathrm{Zn}$ ) decreased significantly over this period, thanks to the smoke reduction after the cessation of IZS activities and the treatment of smelting residues by blocking the source of heavy metal(loid)s, while the mean concentrations of $\mathrm{Zn}(1,287 \mathrm{mg} / \mathrm{kg}), \mathrm{Pb}(762 \mathrm{mg} / \mathrm{kg}), \mathrm{Cd}(7.76 \mathrm{mg} / \mathrm{kg})$, and As $(41.9 \mathrm{mg} / \mathrm{kg})$ in 2018 was still high. Consequently, $\mathrm{Pb}$ and As represented the highest risk of non-carcinogenic adverse health impacts on the local residents, with the non-carcinogenic risk to local children in 2018 still higher than 1, suggesting that children were at high health risk. Therefore, continuous removal of remaining untreated smelting residues and potteries in the IZS area would be a top priority to further reduce the pollution of heavy metal(loid)s in ground dust. In addition, experiments with simulated gastric or lung fluids should be conducted in the future to have real data on potential bioaccesibility of these contaminants. 
Supplementary Materials: The following are available online at https:/ /www.mdpi.com/1660-460 1/18/3/893/s1, Table S1 Exposure parameters for health risk assessment models; Table S2 Reference doses for non-carcinogenic and slope factors for carcinogenic metals; Table S3 Average $I_{g e o}$ values and $I_{\text {geo }}$ classes of heavy metal(loid)s in ground dust; Table S4 Daily exposure amounts, hazard quotients, and hazard index of heavy metal(loid)s in ground dust to adults and children at the IZS area in 2008; Table S5 Daily exposure amounts, hazard quotients, and hazard index of heavy metal(loid)s in ground dust to adults and children at the IZS area in 2018; Table S6 Daily exposure amounts, hazard quotients, and hazard index of heavy metal(loid)s in ground dust to adults and children at the control area in 2008; Table S7 Cancer risk of metal(loid)s in ground dust to adults and children.

Author Contributions: Conceptualization, X.B. and Z.L.; methodology, S.L., H.W., X.L., G.S., and J.C.; software, S.L. and X.L.; validation, Z.L.; formal analysis, Z.L.; investigation, S.L., X.B., Z.L., H.W.; X.L., G.S., and J.C.; resources, X.F.; data curation, Z.L.; writing—original draft preparation, S.L.; writing-review and editing, Z.L. and B.M.; supervision, Z.L. and B.M.; funding acquisition, Z.L., B.M. and H.W. All authors have read and agreed to the published version of the manuscript.

Funding: This research was funded by the National Key Research and Development Program of China (2017YFD0800302 and 2017YFD0800305), Project of Guizhou Provincial Education Department (No. Qian-Jiao-He-KY-Zi [2016]177), Project of Department of Science and Technology of Guizhou Province (No. Qian-Ke-He-Ji-Chu [2019]1053).

Institutional Review Board Statement: Not applicable.

Informed Consent Statement: Not applicable.

Data Availability Statement: Data is contained within the article and supplementary material.

Conflicts of Interest: The authors declare no conflict of interest.

\section{References}

1. Douay, F.; Pruvot, C.; Roussel, H.; Ciesielski, H.; Fourrier, H.; Proix, N.; Waterlot, C. Contamination of urban soils in an area of northern France polluted by dust emissions of two smelters. Water Air Soil Pollut. 2007, 188, 247-260. [CrossRef]

2. Shen, F.; Liao, R.; Ali, A.; Mahar, A.; Guo, D.; Li, R.; Xining, S.; Awasthi, M.K.; Wang, Q.; Zhang, Z. Spatial distribution and risk assessment of heavy metals in soil near a $\mathrm{Pb} / \mathrm{Zn}$ smelter in Feng County, China. Ecotoxicol. Environ. Saf. 2017, 139, $254-262$. [CrossRef] [PubMed]

3. Liu, Y.; Lin, C.J.; Yuan, W.; Lu, Z.; Feng, X. Translocation and distribution of mercury in biomasses from subtropical forest ecosystems: Evidence from stable mercury isotopes. Acta Geochim. 2020. [CrossRef]

4. Adlane, B.; Xu, Z.; Xu, X.; Liang, L.; Han, J.; Qiu, G. Evaluation of the potential risks of heavy metal contamination in rice paddy soils around an abandoned $\mathrm{Hg}$ mine area in Southwest China. Acta Geochim. 2019, 39, 85-95. [CrossRef]

5. Ordóñez, A.; Loredo, J.; De Miguel, E.; Charlesworth, S. Distribution of heavy metals in the street dusts and soils of an industrial city in northern Spain. Arch. Environ. Contam. Toxicol. 2003, 44, 160-170. [CrossRef]

6. Li, Z.; Feng, X.; Li, G.; Bi, X.; Sun, G.; Zhu, J.; Qin, H.; Wang, J. Mercury and other metal and metalloid soil contamination near a $\mathrm{Pb} / \mathrm{Zn}$ smelter in east Hunan province, China. Appl. Geochem. 2011, 26, 160-166. [CrossRef]

7. Svendsen, M.L.; Steinnes, E.; Blom, H.A. Vertical and horizontal distributions of $\mathrm{Zn}, \mathrm{Cd}, \mathrm{Pb}, \mathrm{Cu}$, and $\mathrm{Hg}$ in uncultivated soil in the vicinity of a zinc smelter at Odda, Norway. Soil Sediment Contam. Int. J. 2007, 16, 585-603. [CrossRef]

8. Jiang, J. Status and sustainable development of lead and zinc smelting industry in China. Chin. J. Nonferr. Met. 2004, 14, 52-62. (In Chinese)

9. Wang, H.; Zhang, Y.; Zhang, Z. The current situation of and counterpart measures for the zinc industry of Guizhou. GUIZHOU ENCE 2000, 18, 229-231. (In Chinese)

10. Feng, X.; Li, G.; Qiu, G. A preliminary study on mercury contamination to the environment from artisanal zinc smelting using indigenous methods in Hezhang County, Guizhou, China: Part 2. Mercury contaminations to soil and crop. Sci. Total Environ. 2006, 368, 47-55. [CrossRef]

11. Bi, X.; Feng, X.; Yang, Y.; Qiu, G.; Li, G.; Li, F.; Liu, T.; Fu, Z.; Jin, Z. Environmental contamination of heavy metals from zinc smelting areas in Hezhang County, western Guizhou, China. Environ. Int. 2006, 32, 883-890. [CrossRef] [PubMed]

12. Guizhou Local Annals Compilation Committee. Hezhang County Annals; Guizhou's People Press: Guiyang, China, 2001. (In Chinese)

13. Bi, X.; Feng, X.; Yang, Y.; Qiu, G.; Li, G. Quantitative assessment of cadmium emission from zinc smelting and its influences on the surface soils and mosses in Hezhang County, Southwestern China. Atmos. Environ. 2006, 40, 4228-4233. [CrossRef]

14. Li, G.; Feng, X.; Qiu, G.; Bi, X.; Li, Z.; Zhang, C.; Wang, D.; Shang, L.; Guo, Y. Environmental mercury contamination of an artisanal zinc smelting area in Weining County, Guizhou, China. Environ. Pollut. 2008, 154, 21-31. [CrossRef] [PubMed] 
15. Feng, X.; Li, G.; Qiu, G. A preliminary study on mercury contamination to the environment from artisanal zinc smelting using indigenous methods in Hezhang County, Guizhou, China-Part 1: Mercury emission from zinc smelting and its influences on the surface waters. Atmos. Environ. 2004, 38, 6223-6230. [CrossRef]

16. Lin, W.J.; Xiao, T.F.; Ao, Z.Q.; Xing, J.; Hu, T.X. Limiting factors of waste land revegetation in indigenous zinc smelting areas of western Guizhou. Chin. J. Appl. Ecol. 2007, 18, 631-635. (In Chinese)

17. Sobanska, S.; Deneele, D.; Barbillat, J.; Ledésert, B. Natural weathering of slags from primary Pb-Zn smelting as evidenced by Raman microspectroscopy. Appl. Geochem. 2016, 64, 107-117. [CrossRef]

18. Ma, Z.; Wu, Y.; Fu, T.; Zhang, K.; Lyu, H. Distribution characteristics of heavy metals of different particle sizes in lead-zinc slag. Environ. Sci. Technol. 2015, 38, 149-154.

19. Peng, G. Development of township enterprises and prediction and Countermeasures of environmental protection in Guizhou Province. Environ. Sci. 1988, 9, 64-69. (In Chinese)

20. Peng, Y.; Yang, R.; Jin, T.; Chen, J.; Zhang, J. Risk assessment for potentially toxic metal(loid)s in potatoes in the indigenous zinc smelting area of northwestern Guizhou Province, China. Food Chem. Toxicol. 2018, 120, 328-339. [CrossRef]

21. Zheng, N.; Liu, J.; Wang, Q.; Liang, Z. Health risk assessment of heavy metal exposure to street dust in the zinc smelting district, Northeast of China. Sci. Total Environ. 2010, 408, 726-733. [CrossRef]

22. Hou, S.; Zheng, N.; Tang, L.; Ji, X.; Li, Y.; Hua, X. Pollution characteristics, sources, and health risk assessment of human exposure to $\mathrm{Cu}, \mathrm{Zn}, \mathrm{Cd}$ and $\mathrm{Pb}$ pollution in urban street dust across China between 2009 and 2018. Environ. Int. 2019, 128, $430-437$. [CrossRef] [PubMed]

23. Rahman, M.S.; Khan, M.D.H.; Jolly, Y.N.; Kabir, J.; Akter, S.; Salam, A. Assessing risk to human health for heavy metal contamination through street dust in the Southeast Asian Megacity: Dhaka, Bangladesh. Sci. Total Environ. 2019, 660, 1610-1622. [CrossRef] [PubMed]

24. Zhou, Y.; Wang, L.; Xiao, T.; Chen, Y.; Beiyuan, J.; She, J.; Zhou, Y.; Yin, M.; Liu, J.; Liu, Y.; et al. Legacy of multiple heavy metal(loid)s contamination and ecological risks in farmland soils from a historical artisanal zinc smelting area. Sci. Total Environ. 2020, 720, 137541. [CrossRef] [PubMed]

25. Yang, Y.; Li, F.; Bi, X.; Sun, L.; Liu, T.; Jin, Z.; Liu, C. Lead, zinc, and cadmium in vegetable/crops in a zinc smelting region and its potential human toxicity. Bull. Environ. Contam. Toxicol. 2011, 87, 586-590. [CrossRef] [PubMed]

26. USEPA. Method 7473: Mercury in Solids and Solutions by Thermal Decomposition, Amalgamation and Atomic Absorption Spectrophotometry; U.S. Environmental Protection Agency: Washington, DC, USA, 2007; p. 17.

27. USEPA. Method 3050B: Acid Digestion of Sediments, Sludges, Soils, Revision 2; USEPA: Washington, DC, USA, 1996.

28. Qi, L.; Grégoire, D.C. Determination of trace elements in twenty six Chinese geochemistry reference materials by inductively coupled plasma-mass spectrometry. Geostand. Newsl. J. Geostand. Geoanal. 2000, 24, 51-63.

29. Müller, G. Index of geo-accumulation in sediments of the Rhine River. GeoJournal 1969, 2, 108-118.

30. Aiman, U.; Mahmood, A.; Waheed, S.; Malik, R.N. Enrichment, geo-accumulation and risk surveillance of toxic metals for different environmental compartments from Mehmood Booti dumping site, Lahore city, Pakistan. Chemosphere 2016, 144, 2229-2237. [CrossRef]

31. Liang, Z.; Gao, L.; Zhao, X.; Chen, J.; Xie, Z.; Li, S.; Li, R.; Yang, Z. Assessment of metal pollution, its potential health risks, and origin in different land use types in Zhuhai City, China. Arch. Environ. Contam. Toxicol. 2019, 76, 295-307. [CrossRef]

32. CNEMC (China National Environmental Monitoring Centre). The Background Values of Chinese Soils; Environmental Science Press: Beijing, China, 1990. (In Chinese)

33. Xu, F.; Giovanoulis, G.; van Waes, S.; Padilla-Sanchez, J.A.; Papadopoulou, E.; Magner, J.; Haug, L.S.; Neels, H.; Covaci, A. Comprehensive study of human external exposure to organophosphate flame retardants via air, dust, and hand wipes: The importance of sampling and assessment strategy. Environ. Sci. Technol. 2016, 50, 7752-7760. [CrossRef]

34. Zhang, L.; Chen, P.; Gao, M.; Na, L.; Xiong, X.; Fan, S. Synthesis, characterization, and curing kinetics of novel bismaleimide monomers containing fluorene cardo group and aryl ether linkage. Des. Monomers Polym. 2014, 17, 637-646. [CrossRef]

35. Du, H.; Yin, N.; Cai, X.; Wang, P.; Li, Y.; Fu, Y.; Sultana, M.S.; Sun, G.; Cui, Y. Lead bioaccessibility in farming and mining soils: The influence of soil properties, types and human gut microbiota. Sci. Total Environ. 2020, 708, 135227. [CrossRef] [PubMed]

36. Mendoza, C.J.; Garrido, R.T.; Quilodran, R.C.; Segovia, C.M.; Parada, A.J. Evaluation of the bioaccessible gastric and intestinal fractions of heavy metals in contaminated soils by means of a simple bioaccessibility extraction test. Chemosphere 2017, 176, 81-88. [CrossRef] [PubMed]

37. USEPA. Risk Assessment Guidance for Superfund, Volume I: Human Health Evaluation Manual; EPA 540-1-89-002; U.S. Environmental Protection Agency: Washington, DC, USA, 1989.

38. USEPA. Guidance for Evaluating the Oral Bioavailability of Metals in Soils for Use in Human Health Risk Assessment; U.S. Environmental Protection Agency: Washington, DC, USA, 2007.

39. Candeias, C.; Vicente, E.; Tome, M.; Rocha, F.; Avila, P.; Alves, C. Geochemical, mineralogical and morphological characterisation of road dust and associated health risks. Int J. Env. Res. Public Health 2020, 17, 1563. [CrossRef] [PubMed]

40. USEPA. The Risk Assessment Information System. Available online: https://rais.ornl.gov/ (accessed on 10 December 2020).

41. Li, Z.; Feng, X.; Li, G.; Bi, X.; Zhu, J.; Qin, H.; Dai, Z.; Liu, J.; Li, Q.; Sun, G. Distributions, sources and pollution status of 17 trace metal/metalloids in the street dust of a heavily industrialized city of central China. Environ. Pollut. 2013, 182, 408-416. [CrossRef] 
42. Zhou, J. Geochemistry of Dispersed Elements and Zinc Isotope in Carbonate-Hosted Lead-Zinc Ore Deposits District, Northwest Guizhou Province, China. Ph.D. Thesis, Institute of Geochemistry, Chinese Academy of Science, Guiyang, China, 2011. (in Chinese with English abstract).

43. Liu, J.; Wang, J.; Chen, Y.; Xie, X.; Qi, J.; Lippold, H.; Luo, D.; Wang, C.; Su, L.; He, L.; et al. Thallium transformation and partitioning during $\mathrm{Pb}-\mathrm{Zn}$ smelting and environmental implications. Environ. Pollut. 2016, 212, 77-89. [CrossRef]

44. Valotto, G.; Rampazzo, G.; Visin, F.; Gonella, F.; Cattaruzza, E.; Glisenti, A.; Formenton, G.; Tieppo, P. Environmental and traffic-related parameters affecting road dust composition: A multi-technique approach applied to $\mathrm{V}$ enice area (Italy). Atmos. Environ. 2015, 122, 596-608. [CrossRef]

45. Ordóñez, A.; Alvarez, R.; De Miguel, E.; Charlesworth, S. Spatial and temporal variations of trace element distribution in soils and street dust of an industrial town in NW Spain: 15years of study. Sci. Total Environ. 2015, 524-525, 93-103. [CrossRef]

46. Wu, T.; Bi, X.; Li, Z.; Sun, G.; Feng, X.; Shang, L.; Zhang, H.; He, T.; Chen, J. Contaminations, sources, and health risks of trace metal(loid)s in street dust of a small city impacted by artisanal Zn smelting activities. Int. J. Environ. Res. Public Health 2017, 14, 961. [CrossRef]

47. Zhang, Y.; Wang, J.; Qin, F.X.; Zhang, H. Comparison of sources of metals in road-dust and soil in Guiyang. Acta Sci. Circumstantiae 2012, 32, 204-212.

48. Men, C.; Liu, R.; Xu, F.; Wang, Q.; Guo, L.; Shen, Z. Pollution characteristics, risk assessment, and source apportionment of heavy metals in road dust in Beijing, China. Sci. Total Environ. 2018, 612, 138-147. [CrossRef]

49. Shi, G.; Chen, Z.; Xu, S.; Zhang, J.; Wang, L.; Bi, C.; Teng, J. Potentially toxic metal contamination of urban soils and roadside dust in Shanghai, China. Environ. Pollut. 2008, 156, 251-260. [CrossRef] [PubMed]

50. Li, X.D.; Poon, C.S.; Liu, P.S. Heavy metal contamination of urban soils and street dusts in Hong Kong. Appl. Geochem. 2001, 16, 1361-1368. [CrossRef]

51. Khairy, M.A.; Barakat, A.O.; Mostafa, A.R.; Wade, T.L. Multielement determination by flame atomic absorption of road dust samples in Delta Region, Egypt. Microchem. J. 2011, 97, 234-242. [CrossRef]

52. Keshavarzi, B.; Tazarvi, Z.; Rajabzadeh, M.A.; Najmeddin, A. Chemical speciation, human health risk assessment and pollution level of selected heavy metals in urban street dust of Shiraz, Iran. Atmos. Environ. 2015, 119, 1-10. [CrossRef]

53. Nazzal, Y.; Rosen, M.A.; Al-Rawabdeh, A.M. Assessment of metal pollution in urban road dusts from selected highways of the Greater Toronto Area in Canada. Environ. Monit. Assess. 2013, 185, 1847-1858. [CrossRef] [PubMed]

54. Sun, G.; Li, Z.; Liu, T.; Chen, J.; Wu, T.; Feng, X. Metal exposure and associated health risk to human beings by street dust in a heavily industrialized city of Hunan Province, Central China. Int. J. Environ. Res. Public Health 2017, 14, 261. [CrossRef]

55. Hu, X.; Zhang, Y.; Luo, J.; Wang, T.J.; Lian, H.; Ding, Z. Bioaccessibility and health risk of arsenic, mercury, and other metals in urban street dusts from a mega-city, Nanjing, China. Environ. Pollut. 2011, 159, 1215-1221. [CrossRef] 